\title{
DNA and fingerprint recovery from an arson scene
}

\begin{abstract}
The different methods of both DNA and fingerprint recovery from arson scenes are analysed within this literature. Arson is often used as a mode of concealment due to the wide misconception that fire destroys fundamental evidence. Advances in recent research and technologies have meant that techniques have been developed to further aid and enhance the recovery of evidence that has been exposed to the extreme conditions of a fire. In the forefront of all fire investigations where evidence recovery is paramount, the stages of the fire should be taken into consideration and pre-eminent soot removal techniques carried out in order to expose and visualise any evidence present. Although evaluation of current literature demonstrates that exceptional results from both fingerprints and DNA exposed to fire can be obtained, through different enhancement techniques, further research and developments are required in order to ensure these essential developments are standardised and mandatory to all arson scenes.
\end{abstract}

Keywords: arson, DNA, fingerprints, enhancement, evidence investigations, techniques
Volume 8 Issue I - 2020

\author{
Andrew O'Hagan, Rebecca Calder \\ Nottingham Trent University United Kingdom
}

Correspondence: Andrew O'Hagan, Nottingham Trent University School of Science \& Technology

Erasmus Darwin, Room 230 , Nottingham Trent University,

Clifton Lane Nottingham NGI I 8NS, Direct Line 0II58483।53, United Kingdom, Tel 07850875563,

Email Andrew.ohage@ntu.ac.uk

Received: January 08, 2020 | Published: January 21, 2020

\section{Introduction}

The potentiality and capability of both fingerprint and DNA recovery from an arson scene is worthy of consideration especially as arson is often used as a mode of concealment in relation to evidence linking numerous criminal offences, due to the misconception that the extreme environment of a fire destroys all evidence. It has recently been revealed that this is not the case and valuable criminalising evidence can be recovered.

Deoxyribonucleic acid (DNA) holds the genetic information that every cell in the human body needs to survive. Every individual's DNA is unique to them, obtaining half their genome from their mother and half from their father. DNA can be isolated from $80 \%$ of all human excretions; blood, saliva, urine, semen etc. ${ }^{1}$ New developments in mitochondrial DNA now means full DNA profiles can be obtained from hair follicles, teeth and bone. The chances of two identical twins having the exact same DNA profile is 1 in 70 trillion and has never been reported. ${ }^{1}$ Highlighting its uses in the identification of criminals and arsonists.

Fingerprints are comprised of papillary ridge feature impressions, found within the dermis of the skin. ${ }^{2}$ No two individuals have ever been reported to have the same ridge pattern. ${ }^{3}$ Sir Francis Galton's proposed the probability of two individuals having the same fingerprint was 1 in 64 billion. ${ }^{3}$ Secretions from eccrine glands in the hands (fats, water, sweat, oils) and any contaminants found on the hands or surfaces, adhere so that when a surface comes in contact with the finger a copy of the unique ridge pattern is deposited. ${ }^{3}$ This allows identification of individuals using IDENT1; a database storing the unique fingerprints of anyone who has been arrested or previously convicted. ${ }^{4}$

\section{Discussion}

\section{Arson}

Arson is defined as 'the criminal act of deliberately setting fire to property'. ${ }^{5}$ Statutes of law try arson under the Criminal Damage Act $1971 .{ }^{6}$ This legislation is divided into two subsections; Arson Endangering Life and Arson Not Endangering Life. The classification of endangering life, does not require an individual to be injured, but simply requires the intent to use fire to damage or destroy and in the process endangering life. ${ }^{6}$ It also includes being reckless to the fact that the damage to the property would endanger life, without lawful excuse. ${ }^{7}$ However, if there was a direct attempt to kill, or an individual was killed, this would be classified as attempted murder or murder (class 2). If convicted, the perpetrator could be charged with maximum life imprisonment. ${ }^{7}$ This offence also covers damage to your own property. Not endangering life, requires without lawful excuse, destroying or damaging property of another with the intent to do so. ${ }^{7}$ If convicted, the perpetrator could be charged with a maximum sentence of 10 years imprisonment. ${ }^{6,7}$

It is often easy to identify arson as a crime but difficult to prove and link an individual to the crime. In order to convict an individual, a definite cause of fire must be identified and the prosecution must prove this beyond reasonable doubt, the suspect must be placed at the scene. As the penalty of arson is so high the evidence must be unambiguous ${ }^{8}$ Ignition of a fire is a result of a series of simultaneous chemical, oxidative and exothermic reactions. ${ }^{9}$ A tetrahedron represents the four key principles required to start a fire; oxygen, heat, fuel and chain reaction. Isolation or removal of one of these factors will result in fire extinguishment (Figure 1). ${ }^{9}$

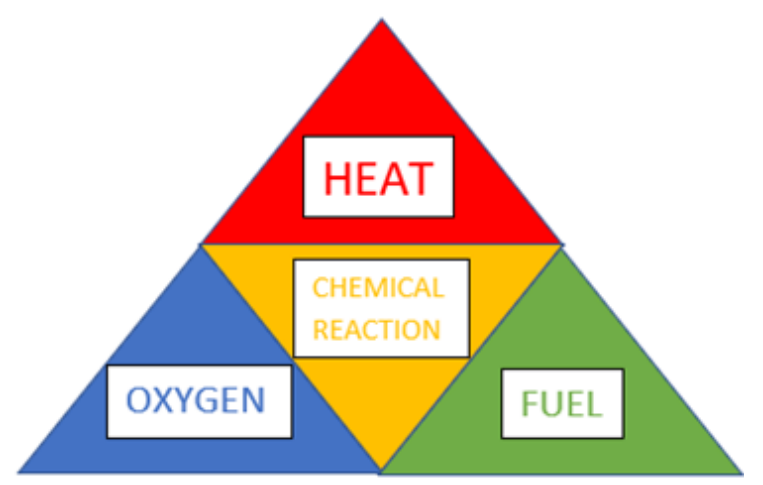

Figure I Fire tetrahedron; 4 key principles required for ignition. ' 
There are 5 main stages to a fire; Pre-heat, Early growth, Flashover, Steady state and Decay. ${ }^{9}$ It is important to understand these stages, as each stage will not only have a different detrimental effect on fingerprints and DNA, but also causes physical changes to the surfaces that they adhere to (Table 1$).{ }^{9}$

Table I Different properties of the 5 main stages of a fire'

\begin{tabular}{|c|c|c|c|}
\hline Fire stage & Heat & Smoke & Flame \\
\hline Pre-heat & Low heat & Little smoke & Small flame \\
\hline $\begin{array}{l}\text { Early } \\
\text { growth }\end{array}$ & $\begin{array}{l}\text { Increased heat (up to } 1000 \\
{ }^{\circ} \mathrm{C} \text { ) }\end{array}$ & Lots of smoke & Flame spread \\
\hline Flashover & $\begin{array}{l}\text { Mass heat ignition } \\
\text { temperatures reached }\end{array}$ & $\begin{array}{l}\text { Less smoke and soot as often } \\
\text { consumed as fuel }\end{array}$ & $\begin{array}{l}\text { Mass flame rapidly spreads as surfaces exposed to thermal } \\
\text { radiation reach ignition temperatures }\end{array}$ \\
\hline Steady state & Mass heat & Mass smoke & Extensive flame \\
\hline Decay & Decreased heat & Considerable smoke & Decreased flame (Increased smouldering) \\
\hline
\end{tabular}

Evidently, the more smoke there is the more soot deposition will occur; the soot fuses to the ridge detail in the print. Thus, protecting the print from extreme temperatures and flames, preserving the unique pattern. As the temperature increase and flames spread, soot can be burnt off in a process known as 'clean burning'. ${ }^{9}$ This is when oxidation reactions occur and the carbon dioxide in the soot is used as a fuel to burn. ${ }^{9}$ This can be detrimental to any DNA or fingerprints that are directly exposed to such conditions; this often occurs at the flashover stage. Ideally a fire will self-extinguish due to the lack of one of the four factors, often this is oxygen. In this instance the whole room will fill with soot due to the last few stages of incomplete combustion, where oxygen is reduced producing carbon as soot. ${ }^{9}$ Thus, protecting the evidence and eliminating the use of extinguishment through other means such as the use of excessive water; which again could reduce the quality of any fingerprints or DNA present. ${ }^{9}$

The basis of a fire investigation is the determination of the cause, origin and development of a fire. Once the investigator has deemed the scene suspicious, crime scene investigators are required to identify and recover any evidence to either prove or disprove arson. There are many indicators of arson; multiple seats of fire, use of accelerant, forced entry, f.raudulent documents, unusual fire development, unusual positioning of fire and the removal of sentimental items. ${ }^{9}$ Often DNA and fingerprints are most likely to be destroyed at the origin of a fire where the temperature is greatest. However, studies have shown that saliva and fingerprints can be recovered from gasoline-petrol bombs after explosion. ${ }^{9}$ Emphasising, that every scene will be exposed to different media and environments and therefore all areas of a scene should be considered for evidence recovery. In particular items likely to be in contact with the perpetrator and points of entry and exit.

\section{Arson statistics}

Overall, as seen in Figure 2 the number of fires deliberately set has decreased, with only a slight increase in the last couple of years. ${ }^{10}$ This decrease could be interpreted as being due to the increasing forensic potential found at arson scenes. Newly developed techniques of soot removal allow the recovery of fingerprints and DNA at fire scenes. This ultimately acts as a deterrent to arsonists. As seen in Table 2 there are two main categories of deliberate fires; primary and secondary. Defined by the location at which a fire is ignited; as seen in Tables $1 \& 2$ Figure $2 .{ }^{11}$

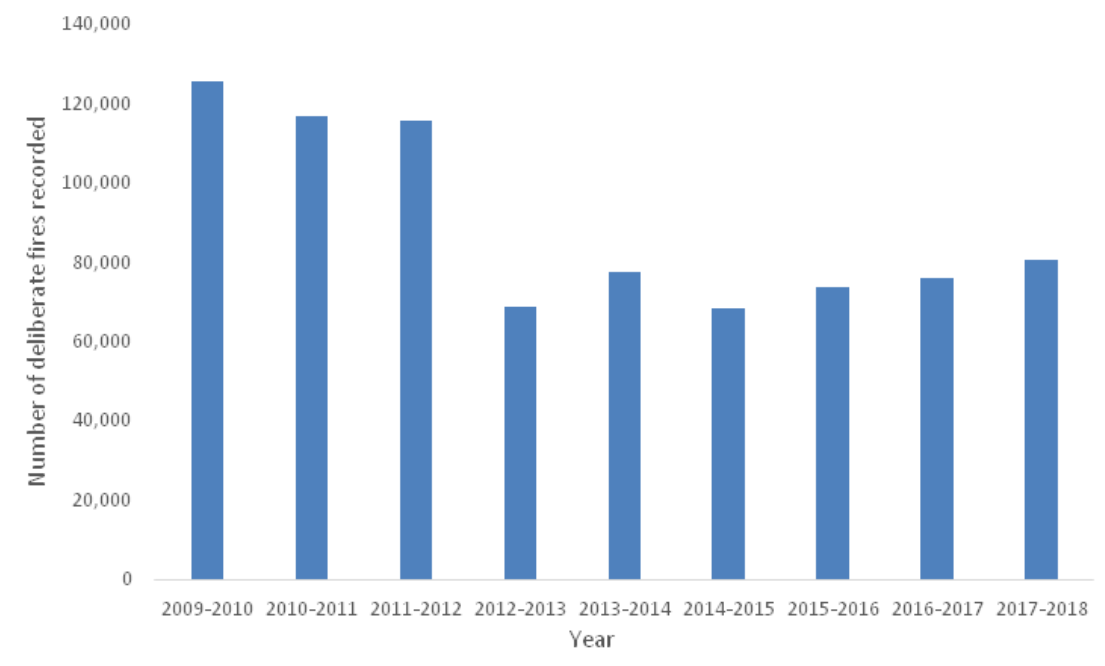

Figure 2 Graph reproduced from statistics showing, the number of fires deliberately set between 2009-2018. ${ }^{9}$ 
Table 2 Deliberate fires attended 2009-2018 and their sub-categories 9

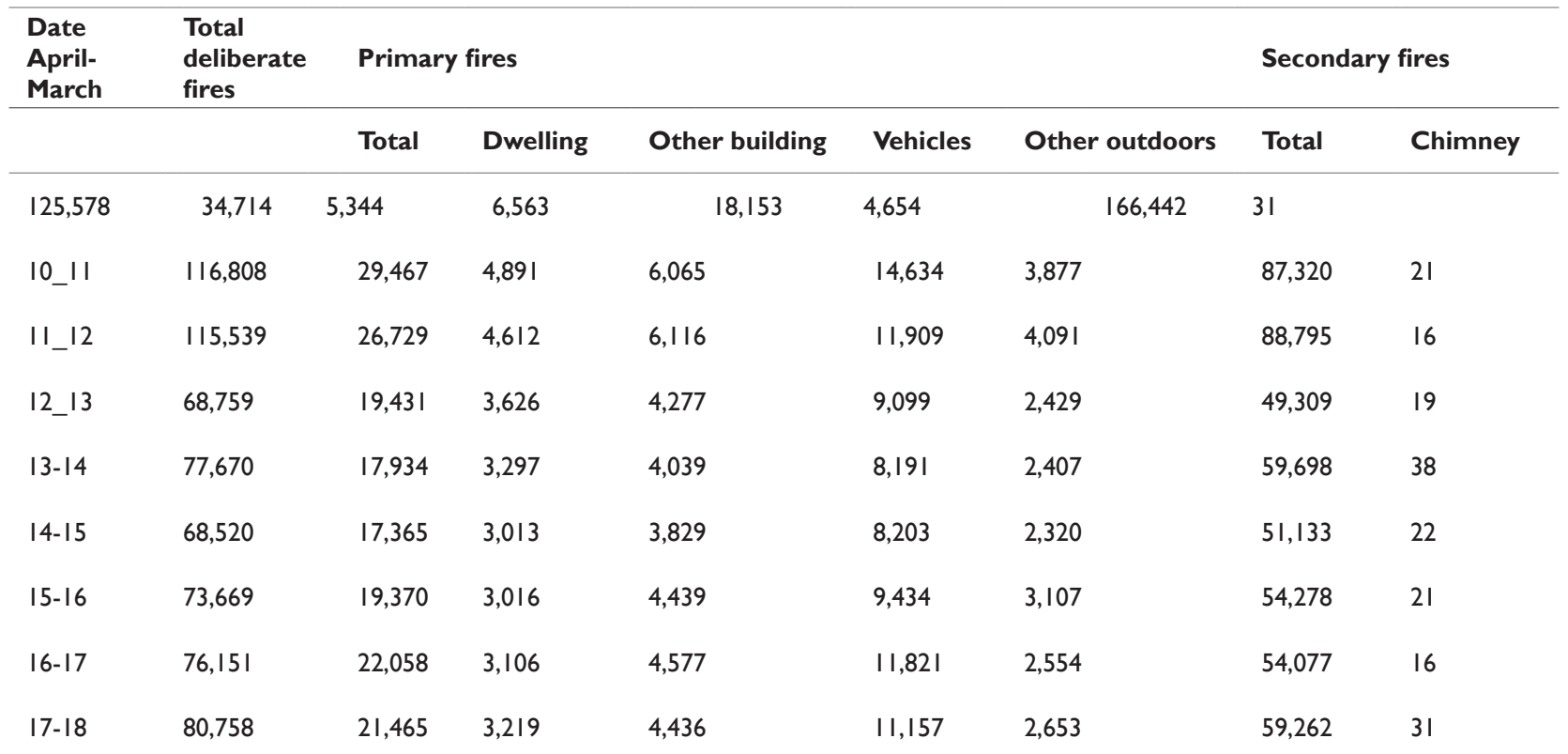

The police and the fire service record and document fires that are believed to be non-accidental. There is a significant difference in these figures; police records are far fewer than the fire service. In 1997 there were 76,500 primary and 104,000 secondary non-accidental fires recorded by the fire service ( $47 \%$ of the total fires recorded).${ }^{10}$ Within the same period, the police only recorded 31,500 arson offences, accounting for only $1 \%$ of total recorded crime. Only 5,000 (7\%) of the arson offences recorded, lead to a person being charged with arson and even a smaller percent of those were convicted. ${ }^{10}$ Between 200405 the fire service recorded 77,700 primary and 256,000 secondary non-accidental fires $\left(70 \%\right.$ of the total fires recorded). ${ }^{10}$ The police only recorded 48,000 arson offences (61\% of total fires) and again only accounting for $1 \%$ of the total recorded crime for that year. On average most crimes have a $20 \%$ 'clean-up' rate; where offenders are prosecuted. However, for arson offences the 'clean-up' rate is considerably lower at $9 \% .{ }^{10}$ Early this year, Damion Harris was sentenced to manslaughter having killed Juozas Tunaitis in a fire he deliberately set at Belgrave House Hotel, back on the $25^{\text {th }}$ July 2018, seen in Figures $3 \& 4 .^{10,12}$

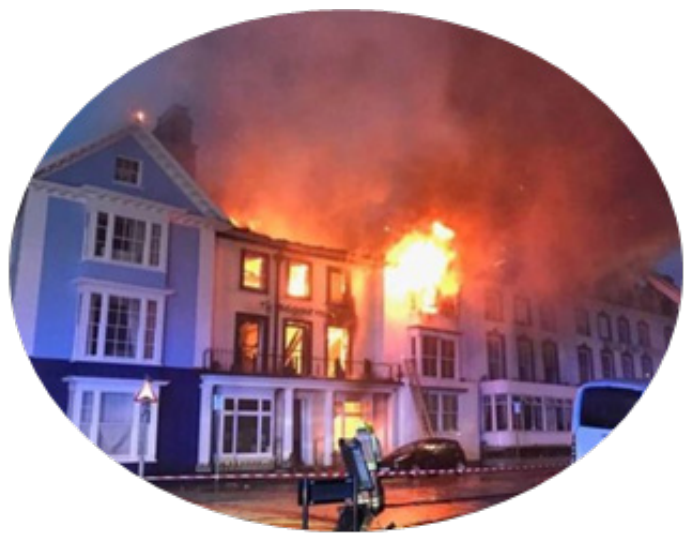

Figure 3 Belgrave House Hotel, Ceredigion. On the $25^{\text {th }}$ July $2018 .^{57}$

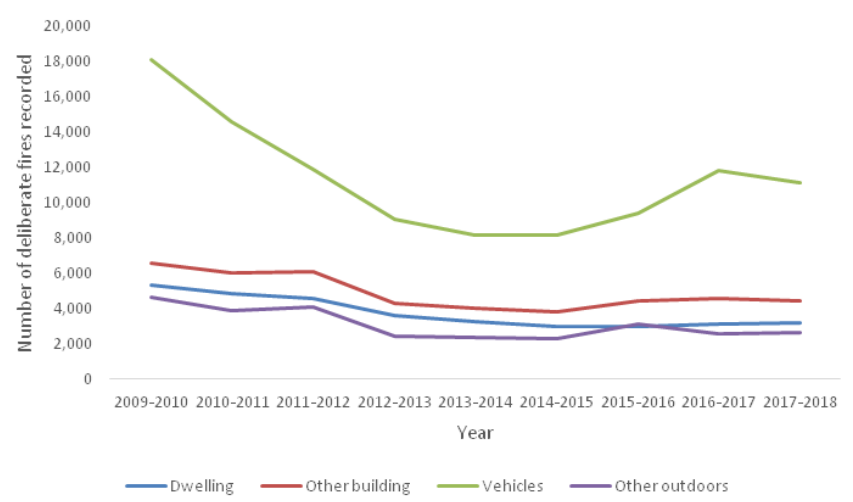

Figure 4 Graph reproduced from statistics showing the number of deliberate fires recorded between 2009-20I8 for all the categories of primary fires.'

Deliberate dwelling fires have increased slightly from the previous year; less than $1 \%$ (Figure 2). ${ }^{10}$ However, it has decreased by $11 \%$ compared to five years ago and even more dramatically at 55\% compared to 10 years age. ${ }^{13}$ In 2003 out of the 721 offenders sentenced in Crown Court, 416 received custodial sentences. ${ }^{14}$ However, out of the 747, sentenced in Magistrates court only 79 received custodial sentences. ${ }^{14}$ This lack of sentencing could be a reason that arson is steadily beginning to increase again, as there is now less of a deterrent from prosecution. Vehicle crime is by far the most common target for arson. Vehicles are targeted for vandalism, hate crime, riots, to destroy evidence and to send warning messages. ${ }^{15}$ Getaway cars for example, vehicles used in robberies are often torched to destroy evidence or to conceal what the vehicle was once transporting. ${ }^{15}$ It is difficult to obtain accurate data due to arson falling under the category of criminal damage. ${ }^{7}$ Often when arson is used as a form of concealment, the crime being concealed is the crime the suspect is charged for. This could also account for the reason why police reports are much lower for that of arson than the fire service. In recent years arson has slowly began to increase, potentially this is due to repeat offenders 
committing the same crimes as they were not sentenced the first time.${ }^{10}$ Arsonists often suffer with pyromania, they are often repeat offenders. ${ }^{16}$ Increasing advances and developments of fingerprint and DNA recovery from arson scenes could lead to stronger evidence being obtained and delivered in court, ultimately leading to more convictions, deterring offenders to use arson as a crime and a method of concealment, resulting in a decline of arson (Figure 5). ${ }^{10}$

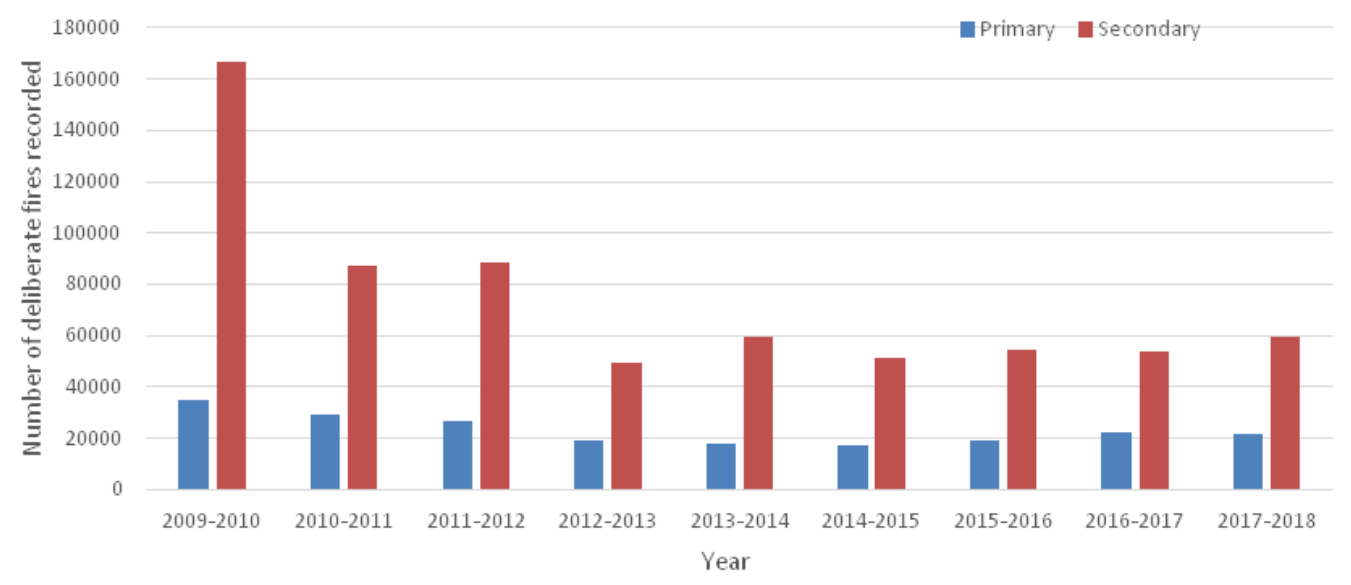

Figure 5 Graph reproduced from statistics showing the number of deliberate fires recorded between 2009-20I8 for both primary and secondary fires. ${ }^{2}$

\section{Soot removal}

As shown in Table 1, there are many different stages to a fire, all of which will have different impacts on the preservation and recovery of both fingerprints and DNA. Early growth, steady state and decay produce the most soot and smoke deposition which can act as a protective layer from detrimental aspects of a fire; flames, extreme temperatures and means of extinguishment. ${ }^{9}$ Other stages of the fire can expose fingerprints and DNA previously protected by soot such as the flash over stage; where oxidation occurs and both smoke and soot are consumed as fuel. ${ }^{9}$

Soot can prevent the evaporation of DNA matrix and fingerprints by adhering to their surface. ${ }^{17}$ As soot deposition is often thick and black in appearance, latent finger-marks and blood staining is not always visible even with the aid of different light emissions. Therefore, techniques have been developed to remove soot in the least detrimental way in attempts to preserve the potential evidence below. Some techniques are very costly and time consuming and therefore not appropriate for the scene to be treated in its entirety. Often areas and objects of interest will need to be selected for treatment. These would be areas that they believe the perpetrator to be in contact with; point of entry and exit, weapons, items moved or alien to the scene.
Different techniques are appropriate for different surfaces based on their characteristics, as seen in Table 3. For both porous and nonporous surfaces light brushing is primarily used as a quick and easy method to remove excess soot. ${ }^{18}$ On non-porous surfaces that are smooth, lifting tape would then be used, followed by either the eraser for fingerprints baked on or sodium hydroxide (detrimental to DNA) if the soot deposition is heavy. ${ }^{18}$ If the surface is textured then the Mikrosil technique would be used. If a large area was to be covered, liquid latex would also be used. ${ }^{18}$ After all of these methods are exhausted more destructive chemical treatments will be carried out. There are considerably less techniques available for porous surfaces due to the water-based methods dissolving the amino acids and substrate mixtures within fingerprints and DNA. Again, light brushing is primarily used, followed by Absorene and chemical treatments. ${ }^{18}$

The presence of fuels such as gasoline, kerosene and diesel oil all reduce the effectiveness of water-based soot removal methods as they are hydrophilic in nature and repel water from the surface. ${ }^{18}$ Methods have been developed to chemically treat surfaces that have been in contact with fuels, the Israeli National Police use ultrasonic baths and in particular, found toluene to reveal more evidence than other solvents. Table $3 .{ }^{19}$

Table 3 Different soot removal methods commonly used, with their advantages and disadvantages

\begin{tabular}{|c|c|c|c|c|}
\hline $\begin{array}{l}\text { Soot removal } \\
\text { Technique }\end{array}$ & Method & Advantages & Disadvantages & Evidence type \\
\hline \multirow[t]{3}{*}{$\begin{array}{l}2 \% \mathrm{NaOH} \\
\text { (Sodium } \\
\text { hydroxide) } \\
\text { Wash }\end{array}$} & $\begin{array}{l}\text { Sodium hydroxide is added to water and can } \\
\text { be applied with a spray or steady stream of } \\
\text { water. }\end{array}$ & - Most favourable & - Not as safe to use & - Fingerprints \\
\hline & & $\begin{array}{l}\text { - Both latent and blood-stained } \\
\text { marks }\end{array}$ & \multicolumn{2}{|c|}{$\begin{array}{l}\text { - Destructive to DNA fingerprints in blood can } \\
\text { be dissolved }{ }^{28}\end{array}$} \\
\hline & & \multicolumn{3}{|c|}{ - Can remove contaminants of both soot and accelerants ${ }^{28}$} \\
\hline
\end{tabular}


Table continue

\begin{tabular}{ll}
\hline $\begin{array}{l}\text { Soot removal } \\
\text { Technique }\end{array}$ & Method \\
\hline & \\
$\begin{array}{l}2 \% \text { Sulfo-salicylic } \\
\text { acid }\end{array}$ & $\begin{array}{l}\text { Sprayed to fix latent ridges onto their surfaces } \\
\text { before being placed into a sonic bath. }\end{array}$
\end{tabular}

acid before being placed into a sonic bath.

silicone rubber casting (Mikrosil)

Mikrosil is mixed with the Mikrosil hardener, this paste is then applied to the surface and allowed to set before being removed.
Advantages

Disadvantages

Evidence type

- Non-porous surfaces

- Can remove heavy soot

- Can be used alongside lifting tape ${ }^{28}$

- Fix latent ridge impressions on

- Does not work if fuels are present

- Fingerprints

- Non-porous surfaces

- Used in conjunction with ultrasonic bath

- Non-porous textured surfaces

- Must also use the ultrasonic bath to remove soot (limited on size of objects)

- Used on 3D surfaces, or in moulded impressions ${ }^{24}$

- Expensive to use

- Fingerprints in blood

- Useful on textured surfaces, can get into the grooves ${ }^{27}$

- Time consuming using a paste and waiting for it to harden ${ }^{27}$

- Can only be used on very small areas

- Not suitable for porous surfaces

- Fingerprints

- Non-porous surfaces with water and soap.

water

Sponge like material consisting of; flour, salt,

Absorene soft and rubbed in one direction on the soot coated surface ${ }^{24}$

- Porous surfaces
N/A - Fingerprints

N/A - Fingerprints

- Wash away amino acids in fingerprint (so cannot use DFO or Ninhydrin)

- Cannot use if fuels are present as they are hydrophilic in nature, repelling the water ${ }^{24}$
Contains water, gasoline, toluene, xylene,

Ultrasonic bath chloroform, ethanol, acetone, hexane, diluted sulfuric acid and detergent ${ }^{24}$

Liquid latex along with a thickening agent and

Liquid latex colourant can be sprayed through a spray gun with a suppressor onto surfaces, only dried can be peeled off, removing the soot. ${ }^{26}$
- Fingerprints in or previously in contact with gasoline ${ }^{24}$

- Non-porous surfaces

$$
\text { - DNA }
$$

- Limited with the number and size of the objects to - Fingerprints be fingerprinted

- Objects must be removed from the scene - DNA for processing

- Good for loosening soot not as good for removing it, better to use in conjunction with something else

- Can be used to treat large areas and whole scenes if necessary

- Treatment can be carried out at the scene ${ }^{25}$

- Peeled away from surface once turns opaque, only takes $5-20$ mins $^{26}$

- Most successful technique in literature
- Works best on lower porosity surfaces not porous surfaces

- Fingerprints

- Must be applied as a spray and has to be thinly - DNA coated ${ }^{25}$

- If too much is applied 'skinning over' may occur and damage the evidence

- Sometimes bloodstaining adheres to the latex and therefore the latex needs to be examined before disposal ${ }^{27}$

- Method can be repeated as many times as necessary ${ }^{27}$

- Some items can be dipped in liquid latex at the $\mathrm{lab}^{27}$ 
Table continue

\begin{tabular}{|c|c|c|c|c|}
\hline $\begin{array}{l}\text { Soot removal } \\
\text { Technique }\end{array}$ & Method & Advantages & Disadvantages & Evidence type \\
\hline & & - Non-porous surfaces & & \\
\hline \multirow[t]{3}{*}{ Eraser } & $\begin{array}{l}\text { Light rubbing of the surface with a pencil } \\
\text { eraser, mostly used on metal objects for 'baked } \\
\text { on' marks }{ }^{25}\end{array}$ & - Heavy soot deposition & - Can rub away ridge detail & - Fingerprints \\
\hline & & - 'Burnt on' prints ${ }^{25}$ & \multicolumn{2}{|c|}{ - Can remove and flake away dried blood } \\
\hline & & - Porous surfaces & - Not suitable to use on a sc & ene in its entirety \\
\hline \multirow[t]{5}{*}{ Light brushing } & $\begin{array}{l}\text { Allows carbon to adhere to the oil residue } \\
\text { within the print using a fiberglass fingerprint } \\
\text { brush }^{24}\end{array}$ & $\begin{array}{l}\text { - Always used first to lightly } \\
\text { remove excess soot }{ }^{25}\end{array}$ & $\begin{array}{l}\text { - Cannot enhance prints } \\
\text { and can only be used } \\
\text { lightly }\end{array}$ & - Fingerprints \\
\hline & & $\begin{array}{l}\text { - Often used primarily by CSI's } \\
\text { as part of their daily kit }\end{array}$ & $\begin{array}{l}\text { - Cannot remove heavy } \\
\text { soot deposition }\end{array}$ & $\begin{array}{l}\text { - DNA (blood } \\
\text { if dry) }\end{array}$ \\
\hline & & - Fast, cheap and effective & \multicolumn{2}{|c|}{$\begin{array}{l}\text { - Time consuming to use on a scene in its } \\
\text { entirety }\end{array}$} \\
\hline & & - No skill or training needed & \multicolumn{2}{|l|}{$\begin{array}{l}\text { - Cannot be used on wet } \\
\text { surfaces }\end{array}$} \\
\hline & & - Non-porous surfaces & & \\
\hline \multirow[t]{4}{*}{ Lifting Tape } & $\begin{array}{l}\text { Adhesive coated transparent tapes are placed } \\
\text { onto the soot coated surfaces, allowing the } \\
\text { soot to adhere before the tape and soot is } \\
\text { removed. }\end{array}$ & $\begin{array}{l}\text { - Useful to lift greasy prints left } \\
\text { in fuels }\end{array}$ & $\begin{array}{l}\text { - Cannot remove heavy } \\
\text { soot deposition }\end{array}$ & - Fingerprints \\
\hline & & \multicolumn{3}{|l|}{ - Porous surfaces } \\
\hline & & \multicolumn{3}{|c|}{ - Lifting tape is always carried within a CSI kit } \\
\hline & & \multicolumn{3}{|l|}{ - Simple and cheap to use } \\
\hline
\end{tabular}

On June $24^{\text {th }} 2005$, Metropolitan Police located a body in a canal, the remains were identified as a known drug dealer who was reported in a disturbance at a flat which was subject to arson the day previous..$^{20}$ The tenant of which was the key suspect in the investigation, admitted setting fire to the flat, but denied murder. The flat therefore needed to be examined to see if any blood and fingerprints from the victim could be identified. Significant soot deposition was present on the wood laminated flooring and the surrounding walls. Mikrosil was considered and applied to specific areas of the wooden door frames.
Liquid latex was used along with a thickening agent and colourant which was distributed on both the walls and flooring of the flat, with a suppressor attached to prevent running on vertical surfaces. ${ }^{20} 90 \%$ soot was removed from painted surfaces, $80 \%$ from untreated surfaces and $70 \%$ from the wallpaper. A light source examination was then carried out, followed by ninhydrin and subsequent chemical examinations. Both fingerprints and blood were identified as belonging to the victim, the suspect was convicted of murder. (Figures 6-8). ${ }^{20,21}$

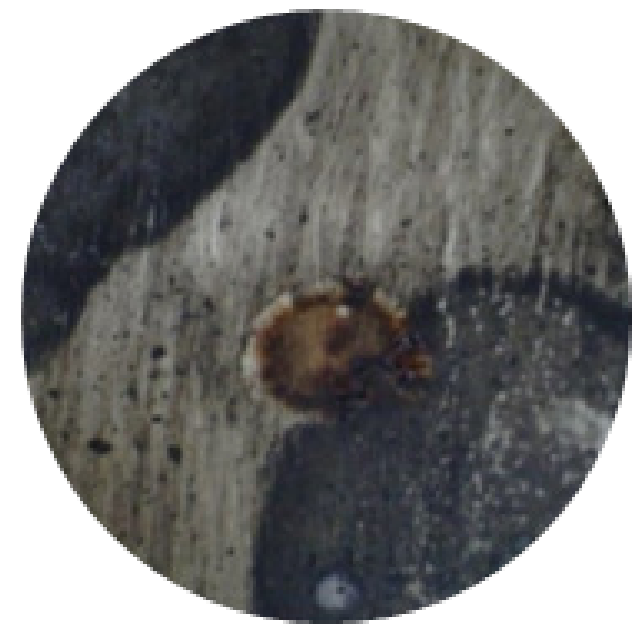

Figure 6 Macroscopic image of blood found after soot removal by liquid latex. ${ }^{27}$

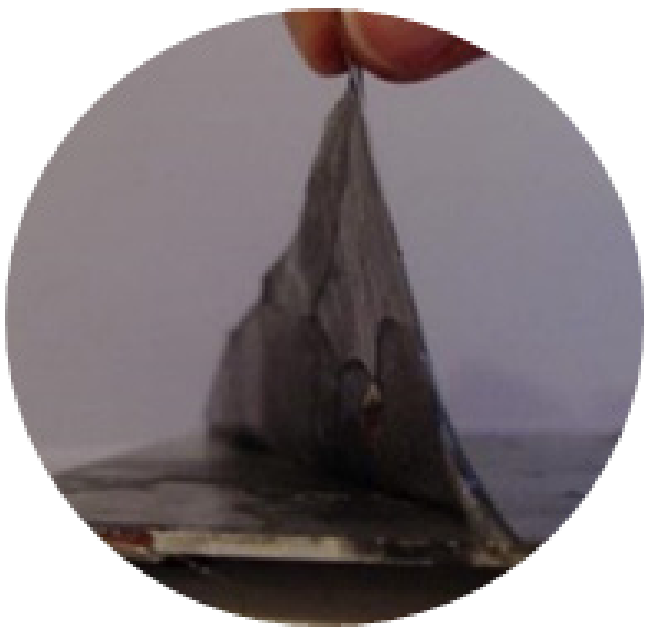

Figure 7 Peeling off dried liquid latex and the soot that has adhered to it. ${ }^{27}$ 


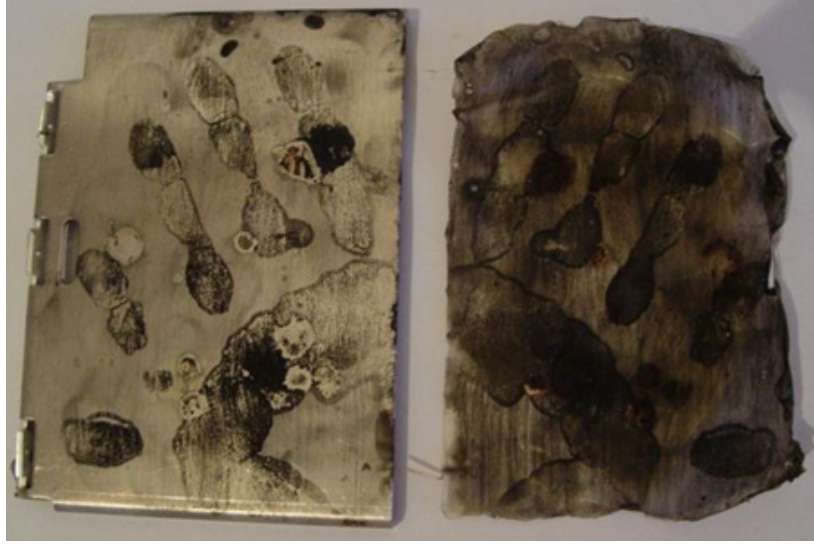

Figure 8 Left is the metal plate once the dried latex has been removed. Right, is once the liquid latex has dried. ${ }^{27}$

\section{Fingerprint recovery: a brief history}

Henry Faulds first discovered fingerprints in 1879 and in 1888 Sir Francis Galton discovered a means of identifying individuals by their fingerprints as he created a method for comparing prints. ${ }^{2}$ He discovered 4 basic delta types; if recovered for all 10 fingers this gave 60,000 different classifications. ${ }^{2}$ This was further developed by Edward Henry who identified five new patterns; arches, tented arches, radial loops, ulnar loops and whorls, this was known as the Henry system, which was adopted by Bengal police creating the first ever national fingerprint bureau. ${ }^{2}$ The importance of having a permanent record of the unchangeable unique finger furrows of criminals was soon established. England created its first fingerprint bureau in 1901, which in 2004 developed into IDENT1 and now holds over 21.8 million sets of prints and over 1.9 million unidentified crime scene marks. ${ }^{4}$

Fingerprints are one of the first features that begin to form at 3-4 months of a developing foetus. ${ }^{22}$ A combination of pressure from the amniotic fluid in the womb and finger growth rate form papillary ridges in the hornier of the skin. ${ }^{22}$ Every individual's fingerprints are unique, even in identical twins. Fingerprints present on the tip of the finger have a functional purpose to aid the movement of objects, as the $3 \mathrm{D}$ structure of a print and the frictional ridges allow the picking up of items. ${ }^{22}$ Despite their development at very early stages of life, they remain the same throughout individual's life time. ${ }^{22}$ Friction ridge patterns are reproduced onto surfaces when secretions from the skin are deposited and adhere to surface materials. ${ }^{9}$ There are two different types of fingerprints; latent fingerprints are not visible to the naked eye and require enhancement through means of physical, chemical and optical treatment, while patent fingerprints, are visible impressions often in blood, food or paint, which require different means of enhancement. ${ }^{9}$

Latent fingerprints consist predominantly of sweat; $98 \%$ water and $2 \%$ of a mixture of skin oils, proteins, salts, urea and organic acids. ${ }^{7}$ There are three main glands found around the body, responsible for secreting sweat. Apocrine glands are found in the axillary regions of the body and the sebaceous glands are found around hair follicles; particularly the face and scalp. ${ }^{17}$ Eccrine glands are primarily responsible for the majority of sweat secretions that create fingerprints, as they are located on the palms and soles of the feet. ${ }^{17}$ There are on average 2-4 million glands distributed around the body, which secrete up to 2-4 litres of sweat an hour. ${ }^{17}$ Studies have shown that there are varying different fingerprint compositions that differ between individuals, over 303 different compounds have been positively identified on the skin surface. ${ }^{17}$

\section{Finger mark recovery considerations:}

There are many different methods and techniques to enhance and recover latent fingerprints. However, when substrates have been subject to arson there are many different factors that need to be considered, based on the circumstances of the fire, in order to assess which enhancement technique is most appropriate. These techniques are analysed and compared in Table 4 . Any recovery technique will greatly depend on the surface material the print is deposited on, which will subsequently affect the constituent of the print that is targeted. ${ }^{3}$ For example, some techniques such as DFO, Ninhydrin and Physical Developer will only work on porous materials ${ }^{3}$ Whereas, Superglue Fuming, Vacuum Metal Deposition and Small Particle Reagent are suitable for non-porous materials. ${ }^{3}$ These methods also greatly depend on the condition of the substrate surface; if it has melted or badly charred, the chances of fingerprint recovery are very slim. ${ }^{9}$

Also, the method of extinguishment needs consideration. A high level of water contamination from the use of hoses and condensation, particularly on porous substrates, will not develop as the amino acids targeted in these techniques e.g. Ninhydrin are water soluble. ${ }^{9}$ Other techniques such as Physical Develop are more appropriate if the substrate is wet, as it reacts with the fat constitutes in the skin that are not water soluble. ${ }^{9}$ A study shows that three different fingerprint recovery methods were successful in recovering fingerprints deposited on transparent foil after being submerged in stagnant water for a week. ${ }^{22}$ In particular, Small Particle Reagent proved to be most advantageous (Table 4). ${ }^{22}$

Table 4 Analysis and comparison of different enhancement techniques suitable for different substrates in different arson conditions

\begin{tabular}{|c|c|c|c|c|}
\hline $\begin{array}{l}\text { Enhancement } \\
\text { Technique }\end{array}$ & Methodology & Advantages & Disadvantages & Temperature \\
\hline \multirow[t]{2}{*}{ Ninhydrin } & $\begin{array}{l}\text { Ninhydrin crystals dissolved in solvent. Sprayed onto } \\
\text { evidence, reacting with amino acids in the sweat to } \\
\text { produce purple colour }{ }^{17}\end{array}$ & $\begin{array}{l}\text { - Latent prints on porous } \\
\text { surfaces }^{17}\end{array}$ & $\begin{array}{l}\text { - At increased temperatures } \\
\text { the paper will turn a darker } \\
\text { colour (purple dye not } \\
\text { seen) }{ }^{20}\end{array}$ & $500^{\circ} \mathrm{C}$ \\
\hline & & - Can be used with DFO & $\begin{array}{l}\text { - Proteins denature } \\
\text { - proteins and amino acids re }\end{array}$ & oved by water' \\
\hline DFO & $\begin{array}{l}\text { DFO also reacts with amino acid secretions, to form } \\
\text { a red coloured fluorescent product }{ }^{17}\end{array}$ & $\begin{array}{l}\text { - Latent prints on porous } \\
\text { surfaces }^{17}\end{array}$ & $\begin{array}{l}\text { - Water can remove amino } \\
\text { acids }\end{array}$ & $500^{\circ} \mathrm{C}$ \\
\hline
\end{tabular}


Table continue

\begin{tabular}{|c|c|c|c|c|}
\hline $\begin{array}{l}\text { Enhancement } \\
\text { Technique }\end{array}$ & Methodology & Advantages & Disadvantages & Temperature \\
\hline \multirow[t]{4}{*}{$\begin{array}{l}\text { Superglue fuming } \\
\text { followed by BY } 40\end{array}$} & $\begin{array}{l}\text { Superglue vapour reacts with eccrine and sebaceous } \\
\text { secretions (moisture and salt) within a fingerprint. } \\
\text { Polymerizing the print that turns the ridge detail } \\
\text { white }^{18}\end{array}$ & $\begin{array}{l}\text { - Dyed with fluorescent } \\
\text { stains (e.g. Basic yellow } \\
\text { 40) to increase contrast }{ }^{18}\end{array}$ & $\begin{array}{l}\text { - Cannot be used on items } \\
\text { that have been } \text { wet }^{18}\end{array}$ & $\begin{array}{l}200^{\circ} \mathrm{C}-750 \\
{ }^{\circ} \mathrm{C}\end{array}$ \\
\hline & & - Non-porous surfaces & \multicolumn{2}{|c|}{$\begin{array}{l}\text { - Hazardous recommended carried out in fume } \\
\text { hood }^{17}\end{array}$} \\
\hline & & \multicolumn{3}{|l|}{ - portable version available ${ }^{17}$} \\
\hline & & \multicolumn{3}{|c|}{ - Applied to materials not previously possible (wood, leather, fabric)' } \\
\hline \multirow[t]{2}{*}{$\begin{array}{l}\text { Iron powder } \\
\text { suspension }\end{array}$} & $\begin{array}{l}\text { Suspension of iron oxide black powder.Adhering to } \\
\text { grease and moisture of the print. }\end{array}$ & $\begin{array}{l}\text { - Detergent used to assist } \\
\text { in soot removal }{ }^{18}\end{array}$ & - Easily evaporated & $200^{\circ} \mathrm{C}$ \\
\hline & & $\begin{array}{l}\text { - Higher contrast and } \\
\text { sensitivity than SPR }\end{array}$ & \multicolumn{2}{|c|}{ - Not effective at extremely high temperatures } \\
\hline \multirow[t]{4}{*}{$\begin{array}{l}\text { Silver vacuum } \\
\text { metal deposition }\end{array}$} & $\begin{array}{l}\text { Evaporation of metal (silver, zinc or gold) and its } \\
\text { deposition onto a latent print to form a film under } \\
\text { vacuum. }^{13}\end{array}$ & - Non-porous surfaces & $\begin{array}{l}\text { - Soot makes it difficult to } \\
\text { resolve marks }\end{array}$ & $900^{\circ} \mathrm{C}$ \\
\hline & & $\begin{array}{l}\text { - Works best on } \\
\text { prints exposed to high } \\
\text { temperatures }^{13}\end{array}$ & - Expensive & \\
\hline & & $\begin{array}{l}\text { - Useful in detecting } \\
\text { degraded samples }\end{array}$ & \multicolumn{2}{|l|}{ - Not all labs have access } \\
\hline & & - Ridge recovery in blood & \multicolumn{2}{|c|}{$\begin{array}{l}\text { - Evidence must be taken to lab (size } \\
\text { restricting) }\end{array}$} \\
\hline \multirow[t]{3}{*}{$\begin{array}{l}\text { Physical } \\
\text { developer }\end{array}$} & $\begin{array}{l}\text { Sequence of aqueous solutions; Maleic acid, followed } \\
\text { by redox, surfactant and silver nitrate solution. } \\
\text { Adhere to the lipid and fatty acids in sebaceous } \\
\text { secretions. }{ }^{17}\end{array}$ & - Used on wet materials & \multicolumn{2}{|l|}{$\begin{array}{l}\text { - Sebaceous secretions not } \\
\text { found on the hands (requires } \\
\text { contamination) })^{13}\end{array}$} \\
\hline & & \multicolumn{3}{|c|}{ - Can be used if wet with petrol ${ }^{17}$} \\
\hline & & \multicolumn{3}{|l|}{ - Porous surfaces } \\
\hline \multirow[t]{6}{*}{$\begin{array}{l}\text { Small particle } \\
\text { reagent (SPR) }\end{array}$} & $\begin{array}{l}\text { Molybdenum particles in detergent sprayed onto } \\
\text { surfaces, reacting with fatty acid deposits, salts in } \\
\text { latent prints to create a grey deposition } . .^{17}\end{array}$ & $\begin{array}{l}\text { - Useful in wet } \\
\text { conditions }^{17}\end{array}$ & $\begin{array}{l}\text { - Not as successful as other } \\
\text { enhancement techniques }\end{array}$ & $800^{\circ} \mathrm{C}$ \\
\hline & & - Used outdoors & - Can affect DNA & \\
\hline & & \multicolumn{3}{|l|}{ - Waxy surfaces } \\
\hline & & \multicolumn{3}{|c|}{ - Versatile, easy to carry to scene } \\
\hline & & \multicolumn{3}{|l|}{ - Assists soot removal } \\
\hline & & \multicolumn{3}{|c|}{ - Salt is most fire-resistant residue } \\
\hline
\end{tabular}

It is important to remember that some components targeted when exposed to water may not be sufficient targets for heat exposure, and often in fires substrates will be exposed to both. ${ }^{7}$ For example, salt is a component that can withstand heat, but dissolves if exposed to water. ${ }^{7}$ Volatile accelerants are commonly used by arsonists to set fires and to increase the rapid spread and the burning rate of a fire. Accelerants include both flammable liquids and combustible liquids; commonly petroleum products. De Haan, in 1979 conducted a three-year investigation into the percentage of arson cases that were submitted to the major crime laboratory. ${ }^{9}$ He concluded that $49 \%$ of all arson cases submitted to the lab involve the detection of accelerants. ${ }^{9}$ These findings were supported by a later investigation by Babrauskas in $2003 .{ }^{9}$ A negative result from the laboratory is not proof that an accelerant was not used as often the fire can consume and evaporate all trace evidence. Therefore, this percentage could be considerably higher and emphasises how common accelerants are to arson scenes. As a result, it is important to understand how the presence of these volatile liquids can impact fingerprint recovery techniques. There are considerable amounts of contrasting literature surrounding the effects of flammable liquids on latent fingerprints. Tyranski Petraco, found that the presence of gasoline in a plastic bottle caused the plastic to turn slightly soluble allowing the friction ridge impression to be moulded into the plastic that was then later recovered by silicone casting. ${ }^{23}$ However, he also suggested that long immersion in flammable liquids destroyed all latent prints by dissolving the fatty acid constituents. ${ }^{23}$ This was later challenged by the Israeli police in 1990 where $34 \%$ of latent prints on glass slides immersed in gasoline were recovered. ${ }^{17}$ Studies were further conducted with a $65 \%$ success rate on the use of SPR to recover latent fingerprints off incendiary bottles. ${ }^{24}$ However, other literature found that long immersion in flammable liquids common in Molotov cocktails, destroyed all latent marks but Ninhydrin identified finger-marks on the label surface having been subject to the flammable liquid (Figure 9) ${ }^{25}$ 


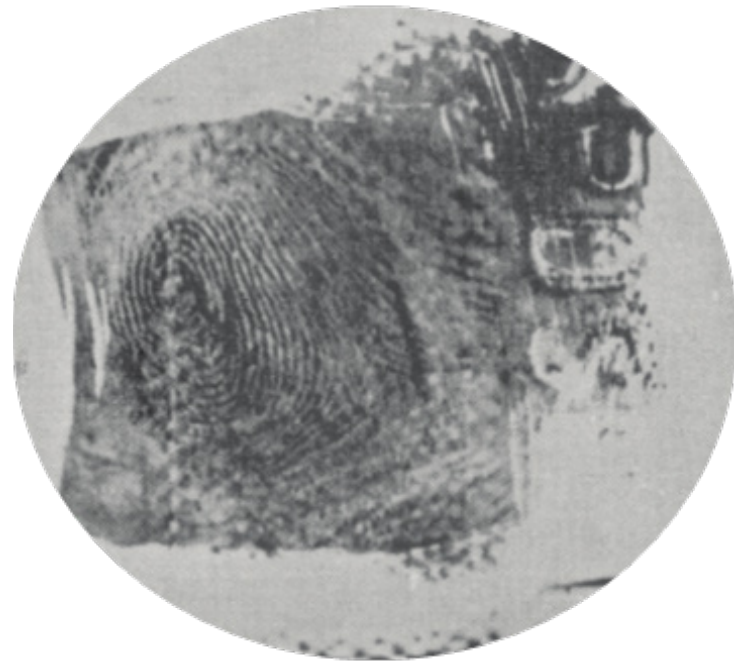

Figure 9 Latent fingerprint developed by light brushing to remove excess soot off the glass from a Molotov cocktail. ${ }^{24}$

Similarly, to the results found by Tyranski Petraco, different effects of a fire can enhance fingerprints. Thermal development exceeding temperatures of $230^{\circ} \mathrm{C}$ can be seen particularly on paper to enhance a latent fingerprint. ${ }^{26}$ It is believed that the degradation of cellulose, the major constituent in paper produces the fluorescence of a finger-mark in the presence of oxygen. Either atmospheric oxygen or the presence of oxygen already within the paper. ${ }^{26}$ Smoke and soot themselves can also act similarly to fingerprint powders, adhering to the constituents in the fingerprint. Flame and soot deposition are now commonly used as a method to develop latent fingerprints. ${ }^{27}$ Camphor crystals are ignited to produce small particle soot deposition and other resinous materials such as, black smoke that are produced during a fire. ${ }^{27}$ Houston Fire Department indicate that this method is much more successful at higher temperatures. ${ }^{27}$ Fingerprints are also known to be 'baked on' to metal surfaces when subject to extreme temperatures of a fire. ${ }^{28}$ The ionic salt composition within the finger-pint residue corrodes the metal surface, thus leaving a 3D impression within the surface of the friction ridge furrows. The chemical reaction between the fingerprint and the metal surface often occurs at $600^{\circ} \mathrm{C}$ or above..$^{28}$ This process is greatly reliant on a high salt concentration within the fingerprint. ${ }^{28}$ In fires, the increasing temperatures also result in the tarnishing of copper; if heavily secreted fingerprints are deposited onto the copper surface it can prevent tarnishing. ${ }^{7}$ These fingerprints in particular will stand out against the contrasting tarnished background (Figure 10). ${ }^{7}$

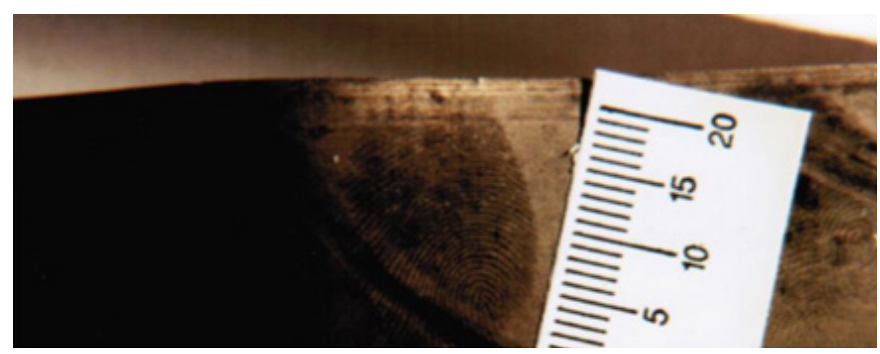

Figure 10 Metal light found directly above origin of fire, the fingerprint is 'baked on'. 38

\section{DNA recovery: a brief history}

Deoxyribonucleic acid (DNA) was first discovered by scientist
Friedrich Miescher in 1871, when he discovered 'nuclein', a molecule from within the nucleus of a cell. ${ }^{29}$ Although it was discovered in 1871 it was not until 1944 that biologist Oswald Avery discovered that nuclein, (renamed to DNA) was the transforming factor that allowed instructions to be carried from one cell to another and identified its hereditary property. ${ }^{29}$ At first, Avery's findings were not widely accepted among the scientific community and it was not until his findings were further supported by experiments carried out by Alfred Hershey and Martha Chase eight years later, that DNA was accepted as the transforming factor that carries all the hereditary information for living organisms. ${ }^{30}$ In 1953, Francis Crick and James Watson published their research on the discovery of the double helix, the structure of DNA with the use of Rosalind Franklins findings. ${ }^{31}$ This was a milestone in the history of DNA as the structure identified how genetic hereditary information was coded, how DNA replicates and how DNA is passed on between generations. This has allowed for rapid advances in molecular biology even to this day. ${ }^{31}$

In 1986, Leicestershire Police were investigating the rape and murder of two school girls; Linda Mann and Dawn Ashworth. ${ }^{32}$ This was the first ever investigation to use DNA fingerprinting and genetic profiling in a forensic case. Semen samples recovered from the girls were compared to the blood sample taken from the suspect Richard Buckland, a teenager with learning difficulties who confessed to the murder. The DNA profile from both semen samples were a match to each other but did not match that of Richard Buckland; exonerating him of their murder. Blood and saliva samples were recovered from 4,000 men living near-by who had no alibi for the murder. Eventually, Colin Pitchfork was identified and convicted of two counts of murder. ${ }^{32}$

DNA is the building block of all life forms. Present in almost every cell in the body, located predominantly in the nucleus but also can be found in the mitochondria. ${ }^{30}$ DNA is the genetic code which makes each individual unique and identifiable, comprised of nucleotides, each of which contains a phosphate sugar and nitrogen base; Adenine, Thymine, Cytosine or Guanine. It is the hydrogen bonds between these bases that create the double helix structure of DNA. ${ }^{30}$ The most useful DNA evidence is that which will yield a full DNA profile. DNA that is degraded is less likely to deliver a full profile. Extinguishment of a fire and the fire itself can degrade DNA, therefore, it is important to understand how different DNA samples are affected by arson.

\section{DNA amplification and profiling}

Short Tandem Repeats (STR's) are sequences of DNA that are repeated normally 8-10 nucleotides and there can be thousands of them within a genome, located in the non-coding region of the chromosome ${ }^{33}$ The number of repeats at any given STR loci are highly variable with the largest amount of polymorphism. Different alleles are inherited from both parents, making them perfect for human identification and discrimination between samples as they create individually unique profiles. STR's are detected through multiplex PCR, primers are designed to amplify specific regions of DNA they anneal to either end of the STR sequence. ${ }^{33}$ Different primers are designed for the 14 recommended STR markers each with different fluorescent labels. ${ }^{34}$ The amplified STR fragments are then separated by capillary electrophoresis, they are placed into wells within polyacrylamide gel, that once a current is run through, will separate the fragments based on their size. With smaller fragments travelling further than that of larger ones, as seen in Figure 14. The matching bands between samples show matching DNA profiles. ${ }^{34}$ 


\section{DNA degradation}

There are many different forms of DNA degradation that can occur when samples are subject to arson. The extreme temperatures that are produced can cause hydrolytic cleavage of phosphodiester bonds. ${ }^{35}$ Phosphodiester bonds link the 3' carbon of one sugar molecule to the 5' of another; producing the strands of nucleic acid that make up DNA. If this occurs in the primer binding region during Polymerase Chain Reaction (PCR) it can prevent binding and produce poor if any amplification. ${ }^{35}$ The longer the strand of DNA the higher the chances of cleaving to occur. Different methods of amplification mean that even some degraded DNA profiles can still yield full or partial profiles that can be used to match individuals directly, or indicate any familial DNA, potentially already on the DNA database. Degraded DNA profiles in particular have been found to contain more short loci that is particularly useful when looking at Short Tandem Repeat Polymorphism (STR). A method has been created to screen samples before typing. In particular, for evidence of critical value that is known to have been exposed to detrimental conditions, resulting in limited DNA quality. ${ }^{36}$ This DNA degradation detection assay can detect the level of viable DNA based on the repetitive and abundant Alu sequences. Multiplex PCR is used with two overlapping Alu amplicons, each with different fluorescence's attached; FAM for long and Quasar670 for the short fragments. The ratio of the two fluorophores gives a quantitative measurement of the degradation of the DNA. A ratio of 2 and above indicates severely degraded DNA, the higher the ratio the higher the degradation. This assay saves time consuming, labour intensive analysis and replication if DNA is not viable. ${ }^{36}$

The same quantitative/ real time PCR method discussed above was also used by Snyder $M$ et al., ${ }^{37}$ to compare the difference in degradation of DNA from blood and sperm when exposed to arson conditions. ${ }^{37}$ The fluorescene based method used Taqman probe to bind to a specific DNA sequence. The probes attached to the blood and semen will have different chemical compounds (dyes) that emit light at different wavelengths. The more DNA present the more fluorescene produced in that wavelength. The purpose was to identify any difference in the semen ratio to blood ratio of amplicon produced. The results showed no significant difference between the degradation of semen to blood samples after exposure to the extreme heat of a fire. However, this experiment did highlight how different substrates can affect the quality of biological evidence. Both polyester and nylon carpets were used, nylon unlike polyester did not absorb the sample, leaving the sample resting on top of the carpet fully exposed to the flame and heat of the fire. Polyester absorbing the sample, provided some protection against the fire and therefore less degraded DNA was recovered from both blood and semen (Figure 11). ${ }^{37}$

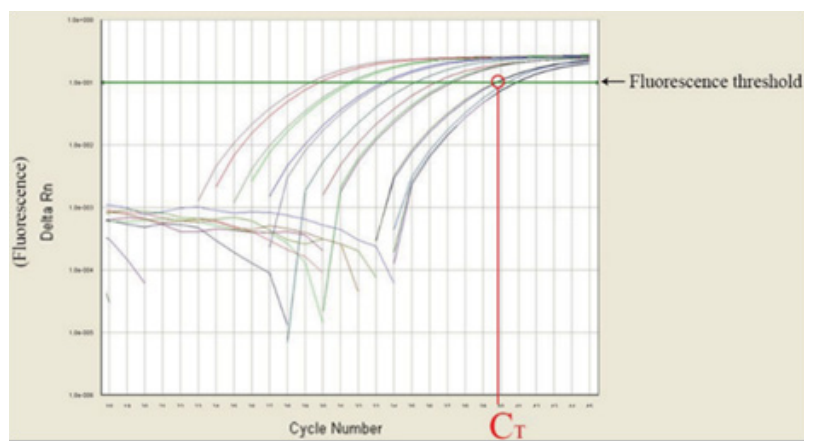

Figure I I Amplicon curve showing the different fluorescene wavelengths and the quantitative measurement of DNA degradation. ${ }^{43}$

\section{DNA recovery considerations}

There are many different factors that can influence DNA degradation; presence of accelerants, burn time and the method of extinguishment. These variables will all differ on different substrates. In an experiment carried out by Vineyard A et al., ${ }^{38}$ different blood detection reagents were used to identify blood samples subject to different variables associated with arson scenes. ${ }^{38}$ Wood blocks were used with different blood dilutions applied, different extinguishment methods were carried out including smothering and covering with water. Unleaded gasoline was added to half the samples to see how accelerant would impact detection methods. Blood testing methods included Bluestar, Luminol and phenolphthalein tetramethylbenzidine (PTMB). The extinguishment of fire by water negatively impacts the ability to detect blood using all three detection methods. Positive blood results from porous combustible surface is more likely to be successful using Luminol or Bluestar. Vineyard A et al., ${ }^{38}$ concluded that even though the porous surface was exposed to the fire for only one-minute, presumptive tests are not sensitive enough to detect DNA samples on charred items. Most laboratories require a positive DNA test before considering the sample for DNA profiling, which may need to be reconsidered in arson scenes where too many variables render presumptive tests inadequate..$^{38}$

In March 2005, a smouldering fire was reported in a basement in Bournemouth. ${ }^{39}$ The fire investigators located the origin of the fire to be the base of a bed, on which the victim was lying. Post mortems indicated that the young woman was stabbed multiple times and strangled to death before the fire started. Forensic scientists called to the scene were interested in identifying blood at the scene and any footwear marks present in the blood. DNA was recovered from a condom at the scene, identifying a male suspect who admitted to having sex with the victim but not to her murder. The primary points to prove were that the suspect was at the scene at the time of the murder. Finding his DNA at the scene would confirm this but also the identification of his footwear marks in her blood. Large soot deposition was present on the laminated flooring of the flat. Luminol was disregarded due to its high production of false positives and inadequate use on non-porous surfaces. Other methods were also ruled out as they are unconventional on large surfaces such as, protein Amido Black. Leucocrystal Violet chemical, was chosen and applied to the scene using a spray mechanism. Footwear marks were identified and photographed in blood and a swab for DNA profiling seized. A full unambiguous DNA profile was created linking to the victim. Although the footwear seized from the suspect did not have DNA relating to the victim, the pattern and size was a match to that found at the scene. It was also an unusual pattern not present on the UK database that holds over 10,000 shoe patterns. This evidence was crucial in convicting the suspect. ${ }^{39}$

Mitochondrial DNA (mtDNA) can be crucial as evidence when nuclear DNA is limited, as mtDNA is present in multiple copies within every cell, the quantity is likely to be greater in degraded DNA samples. A paper towel was recovered from an arson crime scene, subject to extreme temperatures and likely flammable liquids. ${ }^{40}$ Only un-interoperable STR profiles could be produced analysing nuclear DNA. Prior to the towel being sent for fingerprinting, 13 samples from both dark, light and no charred/stained areas were cut out. QIAmp DNA investigator kit was then used for the extraction of DNA on each sample. Nucleotide base sequences from the hypervariable region (HVI and HVII) of the mtDNA fragments were amplified using PCR. Sanger sequencing was then performed and the results aligned 
with Cambridge Reference Sequence and the EMPOP Forensic mtDNA database used as estimation of the matching profile frequency within populations. ${ }^{40}$ Figure 12, shows the results from two different reference samples on the towel and the primary suspects profile, are a confident match. The towel was then subject to Ninhydrin for fingerprint analysis. Evidence is always treated for DNA analysis first as Ninhydrin, Physical Developer and Silver Nitrate can degrade DNA, decrease the number of STR loci that can be successfully typed and inhibit downstream PCR reactions. ${ }^{40}$

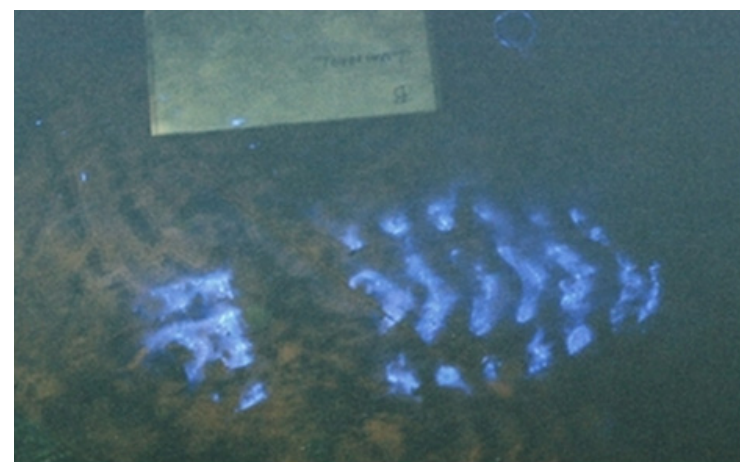

Figure 12 A positive Leucocrystal Violet reaction of a footwear impression in blood. ${ }^{23}$

As previously discussed, different enhancement techniques and blood detecting methods work effectively on different substrates and to different success rates based on the scene itself and subject to different fire variables. Table 5, shows the different methods that have been and are currently the standard used both at scenes and within the laboratory for forensic analysis. (Figure $13 \&$ Table 5). ${ }^{48}$

In a variety of different experiments, a typical house fire has been set to conceal bloodstain patterns, in an attempt to measure and evaluate how temperature of a fire and its extinguishment can affect the quality and ability to yield DNA profiles. ${ }^{41}$ No change was observed in blood characteristics up to a temperature of $41.6^{\circ} \mathrm{C}$. At $297^{\circ} \mathrm{C} 16 / 16$ loci were identified to yield a full DNA profile but all temperatures above $391{ }^{\circ} \mathrm{C}$ no loci could be identified despite preliminary blood test's producing a positive result up to $904^{\circ} \mathrm{C} .{ }^{41} \mathrm{In}$ the same experiment full DNA profiles were created despite negative preliminary blood tests being obtained $[45] .{ }^{41}$ Contrastingly, Klein A et al., ${ }^{42}$ exposed varying objects to different degrees of heat and found that full DNA profiles in $60 \%$ of the tested samples could still be yielded after exposure to $1000^{\circ} \mathrm{C}$, detected by using luminol. ${ }^{42}$ Despite the extreme temperatures, DNA samples can still be recovered from the source and seat of fires, similar to that of fingerprints. In previous studies it has been possible to recover full and partial DNA profiles from all 78 samples recovered from 8 rucksacks post-blast that have been used as Improvised Explosive Devices (IEDs). ${ }^{43}$ DNA from shed skin cells has been amplified using AmpF/STR MiniFiler PCR amplification kit, despite the extreme exposure to pressure and heat that has the potential to degrade DNA. ${ }^{43-50}$

\begin{tabular}{|c|c|c|c|c|c|c|c|c|c|c|c|c|c|c|c|}
\hline & $\begin{array}{c}\text { Position } \\
\text { rCRS }\end{array}$ & $\begin{array}{c}16189 \\
\mathrm{~T}\end{array}$ & $\begin{array}{c}16218 \\
\text { C }\end{array}$ & $\begin{array}{c}16224 \\
\mathrm{~T}\end{array}$ & $\begin{array}{c}16230 \\
\mathrm{~A}\end{array}$ & $\begin{array}{c}16256 \\
\mathrm{C}\end{array}$ & $\begin{array}{c}16259 \\
\mathrm{C}\end{array}$ & $\begin{array}{c}16264 \\
C\end{array}$ & $\begin{array}{c}16311 \\
\mathrm{~T}\end{array}$ & $\begin{array}{c}73 \\
\mathrm{~A} \\
\end{array}$ & $\begin{array}{c}146 \\
\mathrm{~T}\end{array}$ & $\begin{array}{c}150 \\
\mathrm{C}\end{array}$ & $\begin{array}{c}152 \\
\mathrm{~T} \\
\end{array}$ & $\begin{array}{c}195 \\
\mathrm{~T} \\
\end{array}$ & $\begin{array}{c}263 \\
\mathrm{~A} \\
\end{array}$ \\
\hline Sampling 1 & Sample 1 & $T / c$ & $\mathrm{C}$ & $\mathrm{C} / \mathrm{t}$ & A & C & C & C & C & G & $\mathrm{C} / \mathrm{t}$ & $\mathrm{C} / \mathrm{t}$ & $\mathrm{C} / \mathrm{t}$ & $\mathrm{T}$ & G \\
\hline Sampling 2 & Sample 4 & $T / c$ & $\mathrm{C}$ & C & A & $\mathrm{C}$ & $\mathrm{C}$ & C & C & G & $\mathrm{C} / \mathrm{T}$ & C & $\mathrm{C} / \mathrm{T}$ & $\mathrm{T}$ & G \\
\hline Sampling 2 & Sample 9 & $\mathrm{~T}$ & C & C & A & C & C & C & C & G & $\mathrm{C} / \mathrm{T}$ & C & $\mathrm{C} / \mathrm{T}$ & $\mathrm{T}$ & G \\
\hline Sampling 2 & Sample 10 & $\mathrm{~T}$ & $\mathrm{C}$ & C & A & $\mathrm{C}$ & $\mathrm{C}$ & $\mathrm{C}$ & C & G & $\mathrm{C}$ & C & $\mathrm{C}$ & $\mathrm{T}$ & G \\
\hline Sampling 2 & Sample 11 & ND & $\mathrm{C} / \mathrm{T}$ & $\mathrm{C} / \mathrm{T}$ & $\mathrm{A} / \mathrm{G}$ & C & $\mathrm{C} / \mathrm{A}$ & $\mathrm{C} / \mathrm{T}$ & C & $\mathrm{G} / \mathrm{A}$ & $\mathrm{T}$ & C & $\mathrm{C} / \mathrm{T}$ & C & G \\
\hline Sampling 2 & Sample 12 & $\mathrm{~T}$ & $\mathrm{C}$ & $\mathrm{C} / \mathrm{T}$ & A & $\mathrm{C} / \mathrm{t}$ & C & $\mathrm{C}$ & $\mathrm{C} / \mathrm{T}$ & ND & ND & ND & ND & ND & ND \\
\hline \multirow[t]{2}{*}{ Sampling 2} & Sample 13 & $T$ & $\mathrm{C}$ & C & A & C & C & C & C & G & C & C & C & $\mathrm{T}$ & $\mathrm{NI}$ \\
\hline & Suspect & $\mathrm{T}$ & $\mathrm{C}$ & $\mathrm{C}$ & A & $\mathrm{C}$ & $\mathrm{C}$ & $\mathrm{C}$ & $\mathrm{C}$ & G & $\mathrm{C}$ & C & $\mathrm{C}$ & $\mathrm{T}$ & G \\
\hline
\end{tabular}

ND, not determined.

Pink color and two letters indicate a mixture at the position. Upper case letters indicate a major contribution, and lower case letters indicate a minor contribution. Two upper case letters indicate a mixture in equal amounts. Profiles in green color are matching.

Figure 13 Table of results from a paper towel recovered as evidence from an arson, subject to mtDNA analysis. The results show mtDNA profiles from two different samples from the paper towel and the suspects profile. ${ }^{48}$

Table 5 Analysis and comparison of different identification and enhancement techniques of different DNA samples subject to arson conditions

\begin{tabular}{|c|c|c|c|c|}
\hline $\begin{array}{l}\text { DNA } \\
\text { enhancement } \\
\text { technique }\end{array}$ & Method & Advantages & Disadvantages & DNA Type \\
\hline \multirow[t]{4}{*}{ Bluestar } & $\begin{array}{l}\text { Uses modified luminol reagent molecule } \\
\text { to produce chemiluminescence (blue light } \\
\text { emission). }{ }^{22} \text { Luminol reacts with hematin; } \\
\text { produced when bloodstains age }\end{array}$ & $\begin{array}{l}\text { - Detect severely burnt blood } \\
\text { stains }\end{array}$ & - Short shelf life & - Blood \\
\hline & & $\begin{array}{l}\text {-Highest light intensity (but } \\
\text { decreases rapidly) }{ }^{22}\end{array}$ & $\begin{array}{l}\text { - Scene must be darkened } \\
\text { to see emission (not always } \\
\text { possible) }{ }^{22} \text { ] }\end{array}$ & $-800^{\circ} \mathrm{C}$ \\
\hline & & - Very good with aged samples & \multicolumn{2}{|c|}{ - False positives in presence of copper salts } \\
\hline & & - Can be re-sprayed & \multicolumn{2}{|c|}{ - Luminescence only lasts few minutes } \\
\hline Kastle Meyre & $\begin{array}{l}\text { First phenolphthalin reagent is dropped onto } \\
\text { cotton bud containing sample, followed by } \\
\text { hydrogen peroxide. In the presence of blood, } \\
\text { the swab turns pink. }\end{array}$ & - Presumptive blood test & $\begin{array}{l}\text { - Selective, cannot use over } \\
\text { the whole scene }\end{array}$ & - Blood \\
\hline
\end{tabular}


Table continue

\begin{tabular}{|c|c|c|c|c|}
\hline $\begin{array}{l}\text { DNA } \\
\text { enhancement } \\
\text { technique }\end{array}$ & Method & Advantages & Disadvantages & DNA Type \\
\hline & $\begin{array}{l}\text { The ion in the blood and the presence of } \\
\text { hydrogen peroxidase oxidises phenolphthalin } \\
\text { into phenolphthalein. }\end{array}$ & $\begin{array}{l}\text { - Effective and reduces the } \\
\text { amount of evidence recovered }\end{array}$ & \multicolumn{2}{|c|}{$\begin{array}{l}\text { - results harder to obtain if presumptive } \\
\text { chemicals used' }\end{array}$} \\
\hline & & - Non - destructive & \multicolumn{2}{|c|}{ - Only presumptive not conclusive } \\
\hline & & $\begin{array}{l}\text { - Colour change is instant, less } \\
\text { than } 30 \text { seconds }\end{array}$ & \multicolumn{2}{|c|}{$\begin{array}{l}\text { - False positives; saliva, metals and malt } \\
\text { extract }\end{array}$} \\
\hline & & & \multicolumn{2}{|c|}{$\begin{array}{l}\text {-All swabs turn pink eventually as they oxidise } \\
\text { on their own in air }\end{array}$} \\
\hline \multirow[t]{3}{*}{ Hemascein } & $\begin{array}{l}\text { Fluorescein based product, emits green when } \\
\text { excited with blue light }{ }^{22}\end{array}$ & - Long shelf life & $\begin{array}{l}\text { - low light intensity } \\
\text { emission }\end{array}$ & - Blood \\
\hline & & - Detect severely burnt blood stains & & $-904 \circ C$ \\
\hline & & - Out performs Bluestar 22 & & \\
\hline \multirow{2}{*}{ Benzidine } & & - Can be carried out by officers & \multicolumn{2}{|c|}{ - Specific to peroxidases but not blood itself } \\
\hline & & $\begin{array}{l}\text { - Benzidine paper has a shelf life } \\
\text { of a year but can be revitalised by } \\
\text { again being soaked in benzidine } \\
\text { solution }^{54}\end{array}$ & \multicolumn{2}{|c|}{$\begin{array}{l}\text { - False positives can be produced e.g. } \\
\text { vegetable peroxidases }{ }^{54}\end{array}$} \\
\hline \multirow[t]{3}{*}{ PCR } & $\begin{array}{l}\text { Amplification of DNA samples to create } \\
\text { DNA profile using }\end{array}$ & $\begin{array}{l}\text { - Creates DNA profiles for } \\
\text { comparison }\end{array}$ & $\begin{array}{l}\text { - Will not work if the } \\
\text { DNA is too degraded or } \\
\text { fragmented }\end{array}$ & - Blood \\
\hline & & $\begin{array}{l}\text { - Create multiple copies of DNA } \\
\text { over short period of time }\end{array}$ & - Expensive & - Semen \\
\hline & & & \multicolumn{2}{|c|}{$\begin{array}{l}\text { - Knowledge of DNA sequence to produce } \\
\text { primers }\end{array}$} \\
\hline \multirow[t]{4}{*}{ Real time PCR } & $\begin{array}{l}\text { Fluorescene probes bind to targeted DNA } \\
\text { sequence, once synthesised light is emitted. } \\
\text { The higher the wavelength the more binding, } \\
\text { the more DNA present, the less degradation. } \\
43\end{array}$ & $\begin{array}{l}\text { - Multiple sequences can be } \\
\text { analysed at once }\end{array}$ & $\begin{array}{l}\text { - Designed primers have } \\
\text { to have similar annealing } \\
\text { temperatures }\end{array}$ & - Blood \\
\hline & & - Can analyse mixed DNA samples & - Only quantitative & - Semen \\
\hline & & - Only takes 90 minutes & - Will not identify suspect & - Saliva \\
\hline & & - Can save time if DNA is too degrad & ed no further analysis carried & \\
\hline \multirow[t]{3}{*}{ Amido black } & $\begin{array}{l}\text { Protein stain that will react with the proteins } \\
\text { present in blood, but not specific to just } \\
\text { blood. Turns proteins dark blue/black colour, } \\
\text { increasing contrast for identification. }\end{array}$ & $\begin{array}{l}\text { - Enhances patterns in blood, } \\
\text { fingerprints and footwear }\end{array}$ & $\begin{array}{l}\text { - Only used to enhance } \\
\text { patterns in blood such as } \\
\text { fingerprints and footwear }\end{array}$ & - Blood \\
\hline & & - Porous and non-porous surfaces & $\begin{array}{l}\text { - Blood must be on light } \\
\text { coloured surface to create } \\
\text { effective contrast }\end{array}$ & $\begin{array}{l}\text { - Fingerprints } \\
\text { in blood }\end{array}$ \\
\hline & & $\begin{array}{l}\text { - Used at the scene but mostly at } \\
\text { the lab }\end{array}$ & - Corrosive & \\
\hline \multirow[t]{3}{*}{$\begin{array}{l}\text { Leucocrystal } \\
\text { violet }\end{array}$} & $\begin{array}{l}\text { Reacts with the heme- group in blood to form } \\
\text { dark blue/purple product.' }\end{array}$ & - Applied as a wash spray & $\begin{array}{l}\text { - Contains hydrogen } \\
\text { peroxide, if used on heavy } \\
\text { blood stains foaming can } \\
\text { occur and detail can be lost }\end{array}$ & - Blood \\
\hline & & - Presumptive blood test & \multirow[t]{2}{*}{$\begin{array}{l}\text { - Not appropriate for non- } \\
\text { porous surfaces }\end{array}$} & $\begin{array}{l}\text { - Fingerprints } \\
\text { in blood }\end{array}$ \\
\hline & & - Typically used on porous surfaces & & \\
\hline
\end{tabular}


Table continue

\begin{tabular}{ll}
\hline $\begin{array}{l}\text { DNA } \\
\text { enhancement } \\
\text { technique }\end{array}$ & Method \\
\hline Luminol & $\begin{array}{l}\text { Luminol is sprayed onto suspected surface, } \\
\text { giving blue fluorescence under UV light, blood } \\
\text { catalyses oxidation reaction in luminol }\end{array}$ \\
& \\
ABA card & $\begin{array}{l}\text { If haemoglobin is present a mobile antigen- } \\
\text { antibody complex is formed with a } \\
\text { monoclonal antibody. This complex migrates } \\
\text { to test area T where the polyclonal complex } \\
\text { strip }\end{array}$ \\
$\begin{array}{l}\text { is immobilised forming an antibody-antigen- } \\
\text { antibody sandwich and a purple band is } \\
\text { formed. }\end{array}$
\end{tabular}

- Applied at the scene and in the
$\begin{array}{lll}\text { lab } & \text { - Detection limit of } 0.05 \text { ug/ blood }\end{array}$

- Results in 10 minutes

- Less sufficient when sample subject to heat

- Positive results even after being - negative results to human saliva and urine, treated with luminol only works with blood ${ }^{50}$
Phadbas chemical used to detect enzymatic activity of alpha-amylase enzyme found in saliva $^{42}$

Detects the human saliva, alpha-amylase molecule itself and identifies the presence of semenogelin; seminal vesicle antigen ${ }^{42}$
Acid

Phosphatase

Test

Alternate light sources

Christmas Tree Stain
Positive visual identification of a sperm cell. Picroindigocarmine will stain the neck and tail green. Nuclear fast red stains the head red. ${ }^{42}$

- Tests with animal blood gave negative results ${ }^{50}$

- Can be used in conjunction with RSID to perform conclusive test

- Only presumptive test $\quad$ - Saliva

- Carried out at the lab

- False positives can occur; enzyme can be found in other organisms and also secretions in pancreas ${ }^{42}$

- Use in conjunction with Phadebas for confirmatory test ${ }^{42}$

- Can also produce false positives in other mammals - Saliva such as rats ${ }^{42}$

- Can produce false positives in other bodily secretions such as sweat, - Semen

- Quick and easy test blood and breast milk ${ }^{42}$

- Sensitive and specific to human semen

- Still identifiable in less favourable conditions

- Cannot produce false positives with other bodily fluids from females or other species $^{42}$

The enzyme Acid Phosphatase is secreted into semen by male prostate gland, in the presence of Alpha-Naphthyl acid phosphate and Brentamine Fast Blue a colour change occurs to dark purple. ${ }^{42}$

- Very fast presumptive test

- Less than I minute

- Easily carried out at the scene

- Many different light equipment's can be used

- Different colours show a positive result (blue to yellow) ${ }^{42}$

- Presumptive test used at the scene

- Quick and easy to use

- Easily identifiable under a microscope

- Can easily extract DNA from sperm heads
- Shade of purple can vary depending on the activity of - Semen the enzyme

- Age of stain and storage can affect the colouration of colour change ${ }^{42}$

- Vagina secretions can also contain low traces of this enzyme ${ }^{42}$

- Can produce false

positives with different

- Semen secretions

- Some stains may not

fluoresce

- Materials the stains are on can affect fluorescence ${ }^{42}$

- Sperm cells deteriorate the older they are

- Time consuming and requires skill

- Must be carried out at

the lab 
When investigating arson scenes, it is crucial to collect evidence that can link a suspect to that scene in order to secure a conviction of a crime. However, often when arson is used as concealment of other serious crimes such as murder, DNA may need to be collected in order to aid the investigation by identifying a body/ victim. Fire is so destructive, often extensive soft tissue damage renders conventional methods of identification inadequate. Rees K et al., ${ }^{35}$ investigated the effect of heat on the amplification of DNA extracted from the molar tooth of wild boar. ${ }^{35}$ The wild boar was used as a human surrogate to investigate how the flesh mass, bone of the skull, enamel and hard alveolar casing would act as a protective barrier to preserve the DNA of the tooth during incineration caused by the flame of a fire. As a result, pulp showed no visible effects from the fire at temperatures in excess of $625^{\circ} \mathrm{C}$ for 1 hour. As seen in Figure 14, a full DNA profile was obtained that was a clear match to the control; a pre-mortem sample from the victim (Figure 14)..$^{35,51-57}$

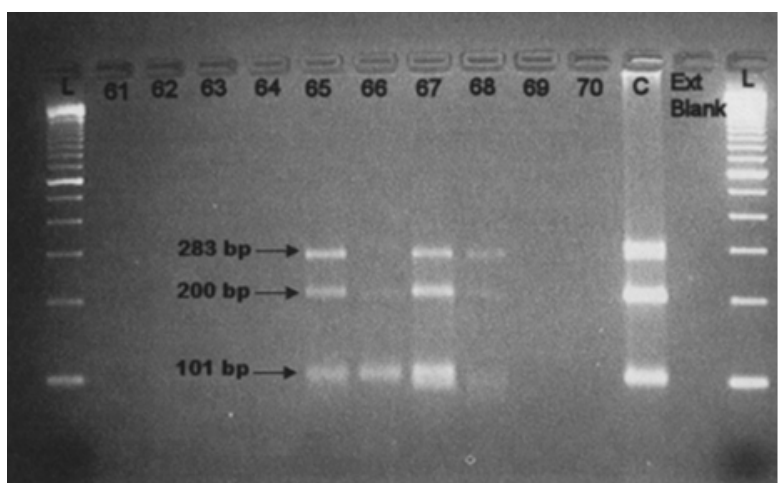

Figure I4 PCR product generated from DNA extracted from wild boar molars exposed to temperatures up to $525^{\circ} \mathrm{C}$. C, control sample $100 \mathrm{bp}$ mol. Well 65; 347ng isolated DNA 66; 93ng isolated DNA 67; $934 \mathrm{ng}$ isolated DNA and $68 ; 43 \mathrm{ng}$ isolated DNA. ${ }^{46}$

\section{Conclusion}

The literature addressed throughout this paper demonstrates that techniques are available to recover both DNA and fingerprints from an arson scene; not only in theory but also in practice. Much like an individual's fingerprints and DNA, every fire is unique. Fires are unpredictable and a variety of different factors will impact its destructive nature. Therefore, there is no single soot removal technique or DNA and fingerprint enhancement technique that will be appropriate for every single fire scene. As future techniques develop and fire development is greater understood services will work collaboratively to best investigate the scene.

Despite these cutting-edge developments in evidence enhancement and recovery from fire scenes, they are not standardised practice at arson crime scenes. Many authorities still lack the skill and knowledge to undergo these procedures within a crime scene. As literature and theories continue to increase within this field of expertise, these principles will be increasingly used in real time cases and their accomplishments will continue to be recognised. Eventually a standardised procedure will be produced and shared among forces so that mandatory DNA and fingerprint analysis and recovery is carried out at every arson scene.

\section{Acknowledgments}

None.

\section{Conflicts of interest}

The author declares there are no conflicts of interest.

\section{References}

1. Shead S. can two people have the same DNA? 2018.

2. Innes B. Bodies of evidence. 2nd edn. Leicester: Silverdale Books. 2001;111-186.

3. Jackson A, Jackson J. Fingerprints. In: Forensic Science. 3rd edn. Essex: Pearson Education. 2011;108-116.

4. Homeland Security UK. IDENT1 Automated Fingerprint System. 2018.

5. Oxford Dictionary. English Oxford Dictionary. 2008.

6. Arson and Criminal Damage. Home Office Counting Rules for Recorded Crime. 2018.

7. O'Hagan A, Banham RB. A review of fingerprint recovery within an arson crime scene. Forensic Res Criminol Int J. 2018;6(5):315-325.

8. Cooke R, Hide R. Principles of fire investigation. Leicester: the institution of fire engineers. 1985;234-237.

9. Icove D, Haynes G. Kirks fire investigation. 8th edn. Hudson Street NY: Pearson. 2018.

10. Home Office. Fire0401: Deliberate fires attended by fire and rescue services. 2018.

11. Fire service circular 21. The Investigation of Fires Where the Supposed Cause Is Not Accidental. 2000.

12. BBC News. Aberystwyth hotel fire: Man 'deliberately' began arson. 2019.

13. Home Office. Fire0401 Table: Number of deliberate fires by fire type, England 2016/17 and 2017/18. 2018.

14. Pretious T. The investigation of fires where the supposed cause is not an accident. 2006.

15. O’Connor J. Accelerants and related burn patterns. In: Vernon J. editor. Geberth Practical fire and arson investigation. Florida: CRC Press. 1993;100-103.

16. Frey R. Pyromania. 2003.

17. Ramotowski R. Lee and Gaensslen's Advances in Fingerprint technology. 3rd edn. London: Chapman and Hall/CRC. 2012.

18. Luche C, Jordan R, Larkin T. Recovery of Bloodstain Patterns from Arson Scenes: Does Soot Removal Using Liquid Latex Damage Underlying Bloodstains? Canadian Society of Forensic Science Journal. $2013 ; 44(2): 47-58$

19. Shelef R, Levy A, Rhima I, et al. Recovery of latent fingerprints from soot covered incendiarised glass surfaces. Journal of Forensic Identification. 1996;46(5):556-569.

20. Larkin T, Marsh B, Nicholas P, et al. Using Liquid Latex to Remove Soot to Facilitate Fingerprint and Bloodstain Examinations: A Case Study. Journal of Forensic Identification. 2008;58(5):540-550.

21. Silke M, Brodbeck M. The Latex Lifting Method for the Recovery of Blood, DNA, and Dermal Ridge Evidence in Arson Cases. Journals of Blood Stain Pattern Analysis. 2011;27(4):3.

22. Smithsonian Channel. Where do fingerprints come from? 2012.

23. Tyranski W, Petraco N. An Interesting Arson Case Involving a Plastic Fingerprint. Ident. News 1981;31(6):9. 
24. Shelef R, Levy A, Rhima I, et al. Development of Latent Fingerprints from Incendiary Bottles: Development of Latent Fingerprints from Unignited Incendiary Bottles; Journal of Forensic Identification. 1996;46(5):556-569.

25. Rimmer S. Latent Fingerprints on Molotov Cocktails or their Fragments Proceedings of the Interdepartmental Fire Research Group Meeting, Wiesbaden, Germany. 2001.

26. Drochioiu G, Sandu I, Olteanu G, et al. Ninhydrin-Based Forensic Investigations I. Fingerprints. International Journal of Criminal Investigation. 2013;1(1):37-58.

27. Kasper S. Lifting Materials. In: Brown E Latent Print Processing Guide. London: Elsevier. 2016;104.

28. Bond J, Phil D. Visualization of Latent Fingerprint Corrosion of Metallic Surfaces. Journal of Forensic Science. 2008;53(4):812-822.

29. Cold Spring Harbor Laboratory. DNA and proteins are key molecules of the cell nucleus. 2011.

30. Pray L. Discovery of DNA structure and function: Watson and Crick. Nature Education. 2008;1(1):100.

31. BBC History. Watson and Crick (1928-). 2014.

32. Channel4 News. Five things we know from 30 years of DNA fingerprinting. 2014.

33. Yeung S, Greenspoon S, McGuckian A, et al. Rapid and High Throughput Forensic Short Tandem Repeat Typing Using a 96 $\square$ Lane Microfabricated Capillary Array Electrophoresis Microdevice. Journal of Forensic Science. 2006;51(4):740-747.

34. El Alfy S, El Hafez A. Paternity testing and forensic DNA typing by multiplex STR analysis using ABI PRISM 310 Genetic Analyzer. Journal of Genetic Engineering and Biotechnology. 2012;10(1):101112.

35. Rees K, Cox M. Comparative Analysis of the Effects of Heat on the PCR $\square$ Amplification of Various Sized DNA Fragments Extracted from Sus Scrofa Molars. Journal of Forensic Science. 2010;55(2):410-417.

36. Nicklas J, Noreault Conti T, Buel E. Development of a Real-Time Method to Detect DNA Degradation in Forensic Samples. Journal of Forensic Science. 2012;57(2):466-471.

37. Snyder M, Aldredge R. Trial by Fire: Comparing DNA Degradation in Blood versus Semen after Fire Exposure. Journal of Forensics Research 2016;7(5):1-10

38. Vineyard A, Hazelrigg E, Connon C. Evaluation of Bluestar ${ }^{\circledR}$ Forensic Magnum and Other Traditional Blood Detection Methods on Bloodstained Wood Subjected to a Variety of Burn Conditions. Journal of Forensic Science. 2019;64(3):878-887.

39. Gorn M, Stafford Allen P, Stevenson J, et al. The recovery of footwea marks in blood at a homicide scene involving a smouldering fire. Journal of Forensic Identification. 2007;57(7):706-716.
40. Bus M, Nilsson M, Allen M. Analysis of Mitochondrial DNA from a Burned, Ninhydrin $\square$ Treated Paper Towel. Journal of Forensic Science. 2016;61(3):828-832

41. Tontarski K, Hoskins K, Watkins T, et al. Chemical Enhancement Techniques of Bloodstain Patterns and DNA Recovery After Fire Exposure. Journal of Forensic Science. 2009;54(1):37-48.

42. Klein A, Krebs O, Gehl A, et al. Detection of blood and DNA traces after thermal exposure. International Journal of Legal Medicine. 2018;132(4):1025-1033.

43. Hoffmann S, Stallworth S, Foran D. Investigative Studies into the Recovery of DNA from Improvised Explosive Device Containers. Journal of Forensic Science. 2012;57(3):602-609.

44. Leitch D. A guide to fatal fire investigations. Leicester: Institution of Fire Engineers. 1993;7-8.

45. Devon and Somerset Fire and Rescue service. Facts and Figures. 2006.

46. Dominick A, Daéid N, Bleay S. The Recoverability of Fingerprints on Nonporous Surfaces Exposed to Elevated Temperatures. Journal of Forensic Identification. 2010;61(5):520-536.

47. Deans J. Recovery of Fingerprints from Fire Scenes and Associated Evidence. Science \& Justice. 2006;46(3):153-168.

48. Dominick A, Daéid N, Bleay S. The Recoverability of Fingerprints on Paper Exposed to Elevated Temperatures Part 1: Comparison of Enhancement Techniques. Journal of Forensic Identification. 2018;59(3):325-339

49. Bilous P, McCombs M, Sparkmon M, et al. Detecting burnt blood samples with Light-Emitting blood enhancement reagents. American Academy of Forensic Sciences. 2010;62(1):1-6.

50. Tontarski K, Hoskins K, Watkins T, et al. Chemical Enhancement Techniques of Bloodstain Patterns and DNA Recovery After Fire Exposure. Journal Forensic Science. 2009;54(1):37-48.

51. Larkin T, Marsh N, Larigan P. Using Liquid Latex to Remove Soot to Facilitate Fingerprint and Bloodstain Examinations: A Case Study. Journal of Forensic Identification. 2008;58(5):540-550.

52. Bradshaw G, Bleay S, Deans J, et al. Recovery of Fingerprints from Arson Scenes: Part 1 - Latent Fingerprints. Journal of Forensic Identification; Alameda. 2008;58(1):54-82.

53. Trapecar M. Fingerprint recovery from wet transparent foil. Egyptian Journal of Forensic Sciences. 2012;2(4):126-130.

54. Spawn M. Effects of Fire on Fingerprint Evidence. 2015.

55. Forensic Resources. Serology - Blood and other Bodily Fluids. 2018.

56. Swander C, Stites J. Evaluation of the ABAcard HemaTrace for the Forensic Identification of Human Blood.

57. Alavi S. Blood Tests at the Scene of Crime. Journal of Criminal Law and Criminology. 1969;60(4):531-533. 